\title{
Role and influence of soil microbial communities on plant invasion
}

\author{
Koshila Ravi Ravichandran*, Muthukumar Thangavelu
}

\author{
Root and Soil Biology Laboratory, Department of Botany, Bharathiar University, Coimbatore, Tamilnadu, India, \\ *e-mail: koshilaravi@gmail.com
}

Received: 17 June 2017 / Accepted: 27 October 2017

\begin{abstract}
It is known that plant invasions are of major concern as they result in loss of biodiversity and alterations in ecosystem processes and functions. Although numerous mechanisms have been postulated to find out the reasons behind plant invasiveness, the actual and precise mechanism is still obscure. Soil microbes are considered as one of the important determinants of plant growth and establishment. Plant invasion leads to changes in the composition and structure of soil microorganisms. Most of the earlier studies have focused on the aboveground mechanisms of plant invasion. Recently the belowground mechanisms for plant invasion are being investigated. In this review, we focus on the various hypotheses related to soil microbes in either enhancing or suppressing plant invasions. The interactions between soil microbes with native and non-native plant species, the role of the plant-soil feedback system in the invasion and its impact, the function of mycorrhizal and bacterial symbiosis in plant species invasion and the role of soil biota and changes brought about in soil nutrient cycling and soil enzymes due to plant invasion are also discussed.
\end{abstract}

Key words: soil microorganisms, invasive plant, plant-soil feedback, mycorrhizal fungi, soil enzymes, soil nutrients.

\section{Introduction}

Some plants are introduced into an alien environment either naturally or deliberately where they proliferate and establish successfully. It has been estimated that around 13,000 plant species are growing outside their native range creating their own populations (van Kleunen et al., 2015). A species becomes locally dominant when introduced into a small area proliferates rapidly (Levine et al., 2003) and transforms the multispecies communities into mono-dominant ones. The plant species that alter the natural plant communities are commonly termed as invasive plant species (Colautti \& MacIsaac, 2004). Nevertheless, the factors responsible for plant invasion are still being a primary challenge in the field of ecology. Generally, biological invasion is of major concern as it causes global environmental changes; alter the structure and function of ecosystems, biodiversity loss and also the extinction of species (Davis et al., 2000; Ogle et al., 2003; Mooney \& Cleland, 2001; Vilà et al., 2007). The biogeochemical cycling of nutrients that are influenced by the plant species compositions is also altered due to plant invasion (Herr et al., 2007). The spread of alien plant species depends directly or indirectly on anthropogenic activities (Panetta \& Scanlan, 1995) like trading and travelling across the globe by ships and aircrafts (Moore, 2004). Invasive plant species have the potential to colonize over an extensive area (Richardson et al., 2000) and can affect both, the human economy and health (Mack, 2001). An analysis of the available information on invasive plant biology suggests that biological traits of the invading plant species, the environmental conditions of the invaded ecosystem and their interactions with the native plant community play a key role in the successful establishment of the invasive plant species (Kolar \& Lodge, 2001). Alien plant species are generally strong competitors than indigenous plant species (Blossey \& Not- 
zold, 1995; Vilà \& Weiner, 2004) and compete directly with native plant species for the various resources (Werner et al., 2010).

Soil microorganisms (microbes) residing in the rhizosphere of plants are involved in several important processes. Soil microorganisms, mostly mycorrhizal fungi and bacteria affect the diversity and abundance of belowground soil organisms and thus can be substantial in response to plant invasion (Broz et al., 2007; Scharfy et al., 2010). The compositions of soil microbial community of invasive plants are different and have altered ecosystem functions from those of native plant species (Ehrenfeld, 2003). Numerous studies have shown that soil microbes are one of the key components that either facilitate or inhibit plant invasion (Bever, 2003; Inderjit \& van der Putten, 2010; van der Putten et al., 2013; Inderjit \& Cahill, 2015). Therefore, knowledge on the interactions between soil microbes and exotic invasive plant species provide a better understanding of the ecological roles of the soil biota functioning both at root-soil and root interface (Rout \& Callaway, 2012).

Most of the previous studies indicate that plant invasion could alter the physiochemical properties of the soil (Rout \& Chrzanowski, 2009; Novoa et al., 2014; Kuebbing et al., 2014). Among the different soil physiochemical characteristics, soil temperature, moisture, and $\mathrm{pH}$ are considered as the important factors in litter decomposition, soil nitrogen contents, metabolic activities and community structure of soil microbes (Wang et al., 2011). For instance, soil moisture and temperature increases following the invasion by Acacia saligna (Labill.) Wendl. (Yelenik et al., 2004). Plant invasion also increases soil pH (Kuebbing et al., 2014), but in certain cases, a low or high degree of plant invasion may increase or decrease soil $\mathrm{pH}$ levels (Si et al., 2013). A decrease in $\mathrm{pH}$ could lead to the higher solubility of nutrients like phosphorus in the soil. This may, in turn, promote plant invasion (Herr et al., 2007). These clearly indicate that plant invasion induces alterations in the physiochemical properties of soil. In this review, we focus on the interactions of invasive plant species with soil microbes, its feedback system, and the influence of exotic plant species on soil enzymes; nutrients and the role of soil biota in plant invasibility.

Most of the research on plant invasion has focused on the aboveground (Levine et al., 2003; Zou et al., 2008) than on the role of belowground mechanisms (Wolfe \& Klironomos, 2005). Several mechanisms have been proposed to explain the role of soil microorganisms in plant invasion. Some of the hypotheses that relate soil microbes to plant invasion are enemy release hypothesis, mutualism hypothesis, enhanced mutualism hypothesis, degraded mutualism hypothesis, accumulation of local pathogen hypothesis and novel weapon hypothesis. One of the most pronounced mechanisms is the enemy release hypothesis that states the absence of antagonists during colonization resulting in the successful establishment of invaded plant species (Keane \& Crawley, 2002; Blumenthal, 2009). Hypericum perforatum L., native to Europe, the western part of Asia and northern part of Africa, experienced reduced herbivores in its exotic range than in its native range (Vilà et al., 2005). Similarly, in Ammophila arenaria (L.) Link. invaded regions, the pathogenic nematodes were less abundant than its native regions (Beckstead \& Parker, 2003). Liu and Stiling (2006) in a meta-analysis showed that about fifteen invasive plant species harbored the lower number of phytophagous insect species in their invaded regions than their native regions.

Accumulation of local pathogen hypothesis (Eppinga et al., 2006; Mangla et al., 2008) suggests that invasive alien plant species gather native soil pathogen that restricts native plant spread and growth. For example, the local pathogens accumulated by $A$. arenaria invaded soil decreased the growth and performance of native plant species by creating a negative effect on them (Eppinga et al., 2006).

The Novel weapon hypothesis postulates that invasive plants possess new biochemical weapons that function as strong allelopathic agents for new plant-soil-microbial interactions (Callaway \& Ridenour, 2004; Callaway et al., 2008) and plant-soil feedback systems (Kardol et al., 2006; Kulmatiski \& Kardol, 2008; Barto et al., 2010). Alliaria petiolata (M. Bieb.) Cavara \& Grande in its introduced region in North America suppressed the growth and performance of native plant species by interrupting and decreasing the mycorrhizal fungal mutualists of native plant species through the production of new biochemicals. In contrast, $A$. petiolata in its native range failed to exhibit any inhibitory effect on mycorrhizal fungi (Callaway et al., 2008). The study on phytochemicals produced by $A$. petiolata that suppressed the performance of native plant species further supports the novel weapon hypothesis (Barto et al., 2010).

According to the enhanced mutualism hypothesis, some invasive plant species have a better association with soil mutualists in its introduced ranges than its native ranges that lead to successful invasion (Reinhart \& Callaway, 2006). The degraded mutualism hypothesis states that invasion of an area by non-mycorrhizal plant reduces the abundance of arbuscular mycorrhizal (AM) fungi. Populations of $H$. perforatum introduced into North America were less dependent on AM fungi than the European, native populations. The reduced mycorrhizal dependence was related with finer root architecture compared to the root structure of the plant in the native range (Seifert et al., 2009). 


\section{Interactions between soil biota and invasive plants}

It is important to elucidate how plant-soil interactions may cause evolutionary changes in invasive alien plant species to understand the role of environmental and plant traits differences in the successful establishment of invasive plant species (Mitchell et al., 2006). Numerous soil microbes have been isolated from invasive plant species (Table 1). Soil biota can influence the alien plant invasion through direct and indirect mechanisms (Reinhart \& Callaway, 2006; van der Putten et al., 2007). Assessment of shifts in the microbial communities and their subsequent influence on the competition between native and invasive plant species could provide a better understanding of post-invasion changes (Hawkes et al., 2005; Zhang et al., 2010). Several studies on plant-soil interactions strongly suggest that introduction of exotic plant species has the potential to alter the microbial structure, function and chemical components of the soil. For example, Kourtev et al. (2002) studied the microbial communities of the rhizosphere and bulk soil of two exotic plant species, Berberis thunbergii DC., and Micrstegium vimineum (Trin.) A. Camus., and the native Vaccinium species and found variation in the structure and function of microbial communities in all the three species.

The interaction between microorganisms and plants can vary from mutualism to parasitism. In mutualism, both plants and the associated microbes benefit each other, whereas parasitism is a non-mutual relationship between species, where microorganisms, the parasite, lives at the expense of the plant host (Neuhauser \& Fargione, 2004). Plant-soil microbial interactions of invasive plants differ from their native and non-native ranges (Callaway et al., 2004; Li et al., 2013). For instance, the soil microbial communities of $B$. thunbergii in its native regions differ from its invaded regions (Coats, 2014). Plants selectively influence the rhizosphere microbiota and establish feedback interactions between them (Kardol et al., 2007). Among all the soil biota, most of the terrestrial plants form a symbiotic association with the soil mycorrhizal fungi. Though mycorrhizal associations are usually presumed to be mutualistic, the nature of the association can range from mutualism to parasitism depending upon the plant species and environmental conditions (Johnson et al., 1997; Neuhauser \& Fargione, 2004). Invasive plants generally promote the favorable soil microbes by establishing positive feedback (Batten et al., 2006; Sanon et al., 2011) and suppress the harmful ones (Lorenzo et al., 2010). The invasion of Acacia dealbata Link reduced the abundance of soil bacteria and fungi (Lorenzo et al., 2010). Yang et al. (2014) showed that invasive plant, Solidago canadensis L. affect the composition of mycorrhizal fungi by promoting the beneficial AM fungi and suppressing the detrimental ones. An inva- sive plant species modifies soil microbes in such a way that results in a positive or negative feedback effect (Bever et al., 1997; Suding et al., 2013). Among 201 invasive plant interactions investigated, $39.8 \%$ showed negative and only $18.9 \%$ exhibited positive feedback interactions (Kuebbing $\&$ Nuñez, 2014). Invasive plant species not only interrupts the long-term coevolved interactions among the native plants, but also the native plant-microorganism association (Callaway et al., 2008; Zhang et al., 2010). Changes in the composition of AM fungi were observed over two growing seasons in $S$. canadensis invaded regions (Zhang et al., 2010). These feedback processes may, in turn, affect the ecological processes, species interactions and temporal dynamics of plant communities (Reinhart \& Callaway, 2006). The bacteria, fungi, actinomycetes and other rhizosphere mutualists involved in these interactions include mostly parasites or pathogens (Mitchell \& Power, 2003), mutualists and symbionts (reviewed by Pringle et al., 2009) and saprophytes or decomposers (Allison \& Vitousek, 2004).

The influence of nematodes feeding on an invasive grass $A$ arenaria showed that plant roots were colonized by feeding generalist and not by feeding specialist in the non-native regions (van der Putten et al., 2005). The invasive soil pathogens that affect the natural vegetation have been mostly reported from the forest and ornamental plants. The soil-borne pathogen, Phytophthora cinnamomi Rands that causes root rot and mortality of plant species is considered as one of the most dreadful invaders all over the world (Garbelotto et al., 2006; Reinhart et al., 2010). Prunus serotina Ehrh., is suppressed by soil pathogen in its native region when compared to its non-native regions (Packer \& Clay, 2000; Reinhart et al., 2003). Similarly, high incidence of native soil borne pathogen Fusarium semitectum Berk. \& Ravenel was observed in the rhizospheric soil of an invasive weed Chromolaena odarata (L.) R.M. King \& H. Rob., suppressed the native plant species (Mangla et al., 2008). Nevertheless, the same plant failed to harbour local soil-borne pathogens in an invaded alien area in South Africa (Te Beest et al., 2009). In a recent study pathogenic fungi associated with the roots of an invasive plant species, Vincetoxicum rossicum (Kleopov) Barbarich., were isolated from a highly invaded region and their effect on the growth of both non-native and two cooccurring native plants species were analyzed. The results of the study indicated that the pathogenic fungi increased the growth of $V$. rossicum but their effect on native plant species varied. These results suggest that the fungi colonizing the roots may be beneficial for the invading species and detrimental or pathogenic to the native plant species (Dai et al., 2016).

Mutualistic effects of soil microbes are considered as one of the important factors in determining plant invasiveness. Mutualistic microbes modify plant communities by either facilitating or inhibiting plant invasions depending 


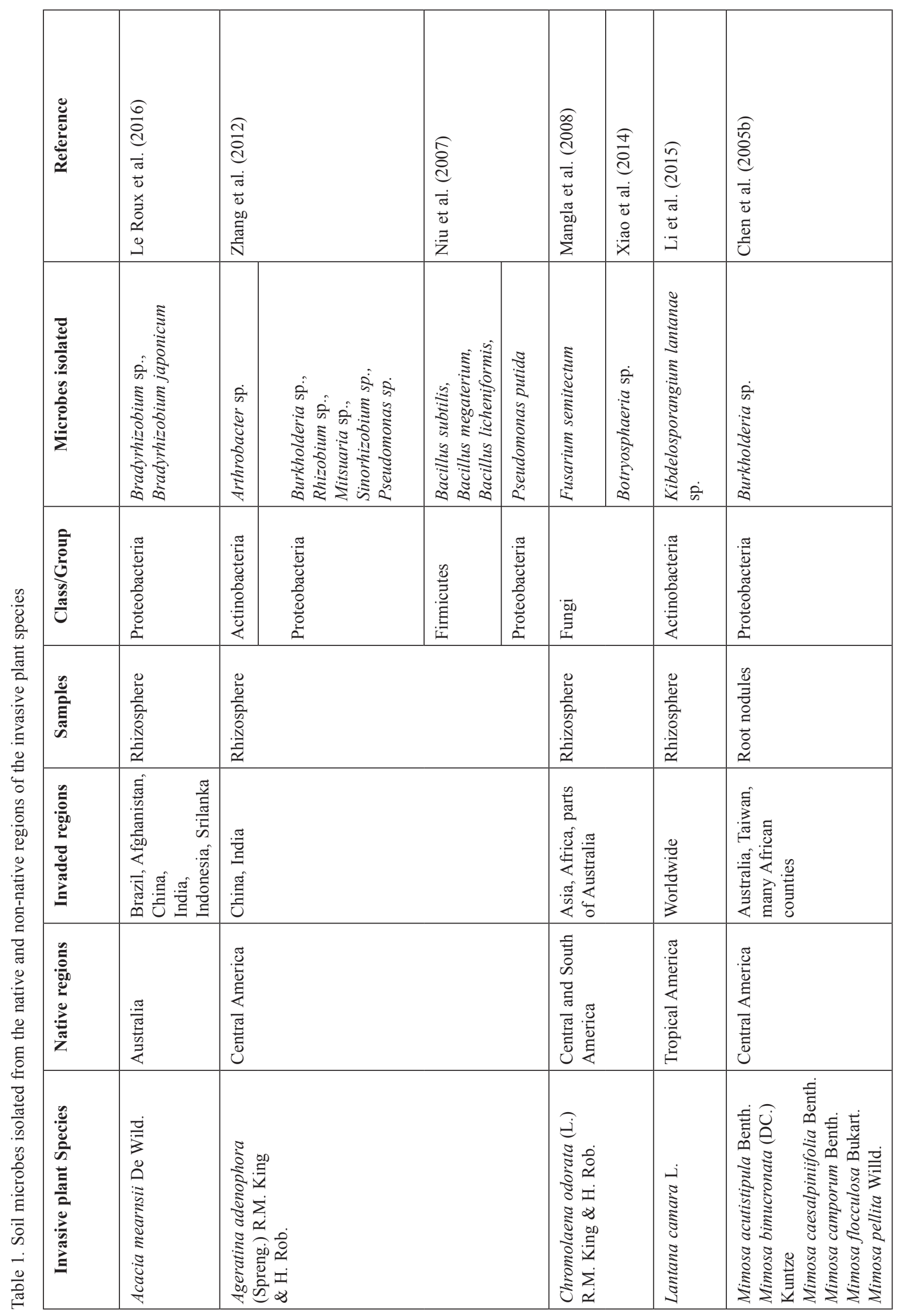




\begin{tabular}{|c|c|c|c|c|c|}
\hline 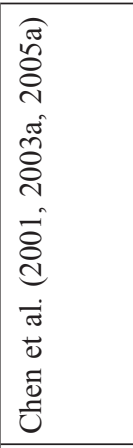 & 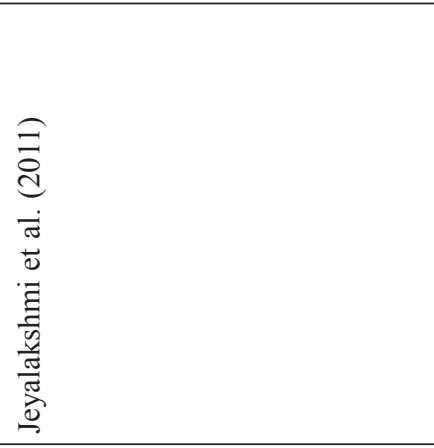 & 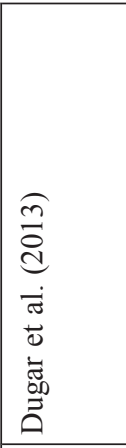 & 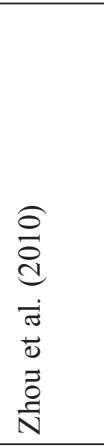 & 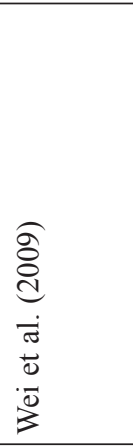 & 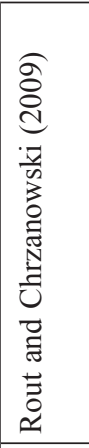 \\
\hline 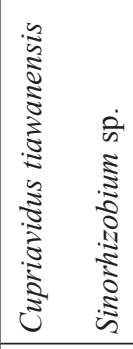 & 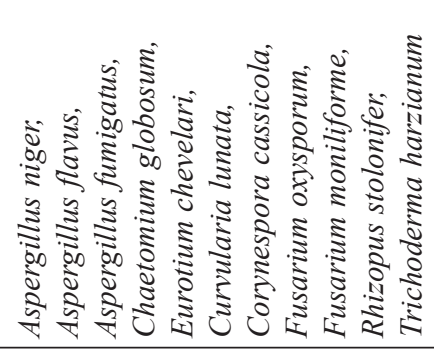 & 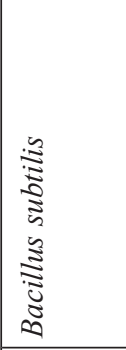 & 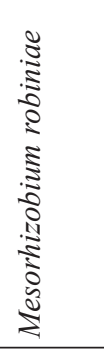 & 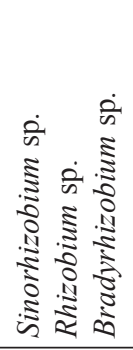 & 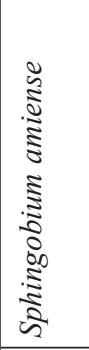 \\
\hline 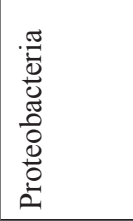 & $\begin{array}{l}\overrightarrow{50} \\
\overrightarrow{5} \\
\overrightarrow{\mid}\end{array}$ & 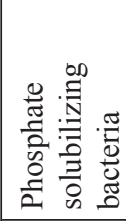 & 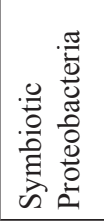 & 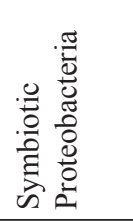 & 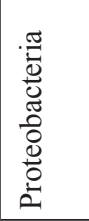 \\
\hline 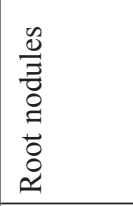 & 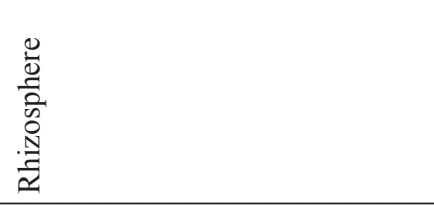 & 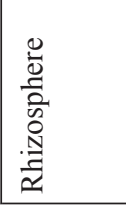 & 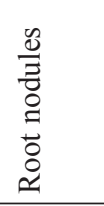 & & 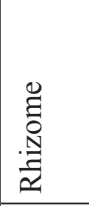 \\
\hline 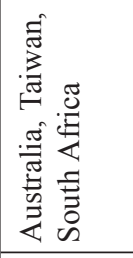 &  & & 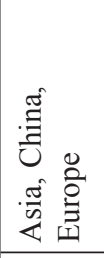 & & 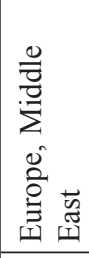 \\
\hline 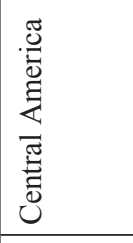 & 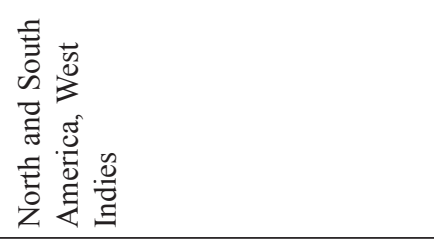 & & 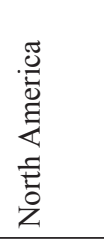 & & 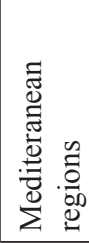 \\
\hline 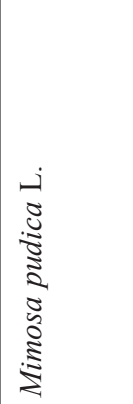 & 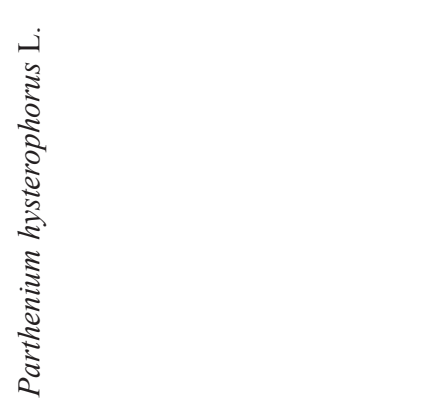 & & 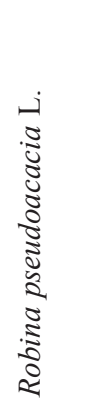 & & 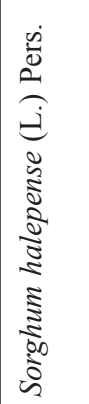 \\
\hline
\end{tabular}


upon the symbiotic interactions in native and non-native habitats (Hawkes et al., 2005; Richandson et al., 2000; Coats \& Rumpho, 2014). The majority of the plants form the symbiotic association with AM fungi (Allen, 1991; Smith \& Read, 2008), nitrogen fixing bacteria (Richardson et al., 2000; Ehrenfled, 2003) and with the wide range of other endophytes (Shipunov et al., 2008; Newcombe et al., 2009). Callaway et al. (2011) studied the impact of soil biota of an invasive tree, Robinia pseudoacacia L., from native, expanded and invasive ranges on nodulation and the nitrogen fixation and found the absence of mutualist and nitrogen fixing organisms in the invaded and expanded soil. In contrast, $R$. pseudoacacia formed nodules with nitrogen fixing bacteria in the native soil. The interactions between nonmycorrhizal fungal endophytes and the AM fungi are known to enhance plant invasiveness (Larimer et al., 2010). Bacterial endophytes help invasive plants by providing a higher amount of phosphorous and iron and also secretes plant growth promoting hormones (IAA), thus increasing the competitive ability of the invasive plants (Rout et al., 2013).

\section{Soil biota and Plant Feedback System}

Plants can modify the nature of the soil structure and chemical characteristics that in turn influence the plant's performance. This is usually referred to as plant-soil feedback (PSF) (Kulmatiski et al., 2008). The PSF is well-known invasion mechanism that operates in a natural system. As already mentioned, PSF can be either positive or negative. The positive feedback is favored mostly by mycorrhizal fungi, nitrogen fixing bacteria and beneficial soil microbes (Allen \& Allen, 1984) and negative feedback are mediated by soil-borne pathogens, herbivores, and parasites (van der Putten, 2001). Soil biota exerts different impacts on native and invasive ranges (Inderjit \& van der Putten, 2010). Positive feedback promotes intraspecific competition and predominance of plants due to the presence of symbiotic mutualists that enhance plant growth thus, also increasing interspecific competition (Bever, 2003). However, the negative feedback regulates and maintains not only the plant abundance but also the coexistence of other plant species (van der Putten et al., 1993; Mangan et al., 2010). The soil biota associating with Centaurea maculosa Lam., have greater negative effects on the plant growth when grown on native European soils in the absence of competitor. But, the soil biota that developed in association with C. maculo$s a$ in the non-native region (North American soil) showed highly positive effects on C. maculosa. Thus soil biota associated with native plant species can enhance the growth of exotic plant through positive feedback effect (Callaway et al., 2004). Similarly, assessment of PSF effect of 61 plant species (invasive, native dominant and native rare) in Canadian grassland and meadows suggested that native rare plants had negative feedback and invasive plants were benefitted from the liberation of soil-borne enemies thus exerting positive feedback (Klironomos, 2002).

An investigation on plant-soil biota feedback of 10 congeneric pairs of native and non-native herbaceous plant species showed more significant negative soil microbial feedback for native plant species when compared to non-native plant species (Agrawal et al., 2005). A comparison between native and non-native soils suggests that the native soil had a more suppressive effect on certain invasive plant species (Maron et al., 2014). Nevertheless, invasive plant species when introduced into a new area leave back the components that suppress the soil biota. AM fungi take part in plant-soil feedback between invasive shrub and native forest understorey species shrub and the woody invasive species change the AM fungal association of native plant (Shannon et al., 2014). The plant-soil interaction of an invasive species Triadica sebifera (L.) Small in its native and an invaded region showed that $T$. sebifera had a negative effect in its native range but always had a positive effect on invaded soil range (Yang et al., 2013), which favors the enemy release hypothesis.

Most of the studies examining plant-soil microorganisms feedback have proved that native plant species often experience negative soil feedbacks (Andonian et al., 2011; Reinhart et al., 2010). A meta-analysis showed that invasive exotic plant species suffer less from negative soilfeedback effect than the native plant species (Kulmatiski et al., 2008). In a greenhouse study, Niu et al. (2007a, b) examined the influence of an invasive plant species, Ageratina adenophora (Spreng.) King \& H. Rob., and three native plant species on soil biota. The results of the study indicate that the soil biota linked with native species had a positive effect on the invasive $A$. adenophora and negative effect on native plants. Similarly, a positive feedback was also noticed in the invaded region for black cherry ( $P$. serotina) to soil microbial communities and negative feedback in the native region (Reinhart et al., 2003). Acacia delbata Link invasion negatively affected the soil fungi and bacteria (Lorenzo et al., 2010). The effect of different species of AM fungi on plant-fungal feedback in serpentine grassland was studied. Among seven AM fungal species (Glomus sp. 1, Rhizophagus intraradices (N.C. Schenck \& G.S. Sm.) C. Walker \& A. Schuessler, Glomus microcarpum Tul. \& C. Tul., Gigaspora gigantea (Nicol. \& Gerd.) Gerd. \& Trappe, Claroideoglomus etunicatum (W.N. Becker \& Gerd.) C. Walker \& A. Schuessler, Scutellospora calospora (Nicol. \& Gerd.) C. Walker \& F.E. Sanders and Rhizophagus fasciculatus (Thaxt.) C. Walker \& A. Schuessler isolated from field soil and trap cultures, only C. microcarpum and C. etunicatum exerted negative feedback response on the growth of their particular hosts (Castelli \& Casper, 2003). Species richness and soil context are important in determining PSF system. The changes caused by the 
invasive grass Aegilops triuncialis L., on the soil microbial populations had a negative effect on two non-native plant species grown in greenhouse conditions (Batten et al., 2008). The performance of the two native plants, Lasthenia californica DC. ex Lindl., and Plantago erecta E. Morrisremained unaffected in both native and invaded soil under field experiment thus leading to positive feedback in certain cases (Batten et al., 2006).

\section{Role of mycorrhizal symbiosis in plant invasion}

Mycorrhizal symbiosis is regarded as one of the key biotic interactions in the biosphere (Mummey \& Rillig, 2006). Soil mutualist favors some of the plant invasions and few of the invasive plant species modify the soil-borne mutualists thus changing the native plant communities (Richardson et al., 2000; Callaway et al., 2008). Invasive exotic plant species also rely on soil microbes and AM fungi for mutualistic facilitation like the native plant species (Richardson et al., 2000). For example, the success of certain plant species like Acer negundo L., Acer platanoides L., Bidens pilosa L., and Solidago canadensis L., in their invaded region, has been attributed to their symbiotic association with mycorrhizal fungi (Reinhart \& Callaway, 2004; Cui \& He, 2009; Sun \& He, 2010). Similarly, C. maculosa, an invasive plant species of North America invaded successfully through mycorrhizal mycelia network in its introduced range (Marler et al., 1999) and the competitive advantage of $C$. maculosa on the resident grass Festuca idahoensis Elmer are mediated by AM fungi (Zabinski et al., 2002). Inoculation of AM fungal species (Rhizophagus irregularis (Blaszk., Wubet, Renker \& Buscot) C. Walker $\&$ A. Schuessler, Funneliformis mosseae (T.H. Nicolson \& Gerd.) C. Walker \& A. Schuessler and Claroideoglomus claroideum (N.C. Schenck \& G.S. Sm.) C. Walker $\&$ A. Schuessler enhanced the growth, phosphorous concentration in roots and shoots of two invasive plant species, Rudbeckia laciniata L. and Solidago gigantea Aiton. (Majewska et al., 2017). Invasive plant species escape from their native enemies by altering the mycorrhizal association and competitive interaction with the native plant species in their introduced range (Shah \& Reshi, 2007; Shah et al., 2008). The facultative mycorrhizal dependence of Bromus tectorum L. has to lead to the successful invasion of this plant species in American sagebrush steppe (Goodwin, 1992). Mycorrhizal mutualists are known to determine the patterns of invasiveness and abundance of few plant species (Levine et al., 2004). Invasive plant species that propagate and proliferate with less mycorrhizal dependency might reduce the AM fungal density in soil (Vogelsang et al., 2004). But in some cases, non-mycorrhizal invasive plant species have proliferated with elevated AM fungal density in the ecosystems (Stinson et al., 2006). The alterations in AM fungal abundance and species richness caused due to exotic plant invasions can either be unfavorable to the native plant species (Shah et al., 2008).

The changes induced in the mycorrhizal fungal communities results in a positive feedback cycle which in turn enhance the plant invasibility (Sun \& He, 2010). Plant invasion may be inhibited due to changes in mycorrhizal fungal community composition (Pringle et al., 2009). When native [Nassella pulchra (Hitchc.) Barkworth, Lupinus bicolor Lindl.] and invasive plant species Avena barbata Pott ex Link and Bromus hordeaceus L., were grown together, the AM fungal community composition was altered (Hawkes et al., 2005). A meta-analysis on AM fungal interactions between native and nonnative plant species suggested that invasions fail to select the direction of shift. This does not support the divergent hypothesis that states plant invasion either promote or decrease the mutualistic association between plants and AM fungi. Though the abundance of AM fungi in both, native and invasive plant species did not differ, the AM colonization was lower in the native plant species when compared with invasive ones (Bunn et al., 2015).

Nonmycorrhizal plant species invasion may reduce the abundance of AM fungi thus negatively influencing the alien plant species that depend on AM fungi. Hence, it further promotes invasion and dominance of non-mycorrhizal plant and hinders the native plant species growth (Vogelsang et al., 2004). One of the nonmycorrhizal invasive plants, $A$. petiolata decreased the proliferation of the native AM fungi and ectomycorrhizal fungi (EMF) (Wolfe et al., 2008). A petiolata reduced the diversity and abundance of AMF due to the production of allelochemicals (Roberts \& Anderson, 2001). Another nonmycorrhizal exotic invasive plant species Tamarix retarded the growth of native plant Populus fremontii S. Watson by interrupting its mutualistic association with AM fungi and EMF (Meinhardt \& Gehring, 2012). An invasive plant, Impatiens glandulifera Royle in a mixed deciduous forest had a negative effect on the mutualistic association between AM fungi and the native plant Acer pseudoplatanus L. (Ruckli et al., 2014). The invasion of another nonmycorrhizal plant, Reynoutria japonica Houtt. decreased the species richness and AM fungal abundance due to reduction of organic carbon inputs (Zubek et al., 2016). AM fungi enhance the extensive spread and invasiveness of Solidago canadensis more than the native Stipa bungeana Trinius plant species (Sun \& He, 2010). This clearly shows that AM fungal species facilitates the growth of nonnative species (Yang et al., 2014). Similarly, the invasiveness of Ambrosia artemisiifolia L. has been reported due to the positive feedback effect of AM fungi on growth, development, and spread of the species (Fumanal et al., 2006). One of the most aggressive weed, $A$. adenophora increased the AM fungal abundance 
in highly invaded areas than the non-invaded regions (Niu et al., 2007a). Pinus and Eucalyptus species were able to invade in the Southern hemisphere only after the introduction of specific EMF (Richardson et al., 1994; Vellinga et al., 2009). Eucalyptus has become invasive in Spain following the introduction of the Australian EMF species $P i$ solithus (Diez, 2005).

\section{Role of bacterial symbiosis in plant invasion}

Although the association between plant root and nitrogen fixing bacteria is one of the most studied symbiotic associations, its importance in plant invasion is largely ignored (Richardson et al., 2000). Invasive plants may form the mutualistic association with nitrogen fixing bacteria Rhizobium and actinomycetes Frankia (Clawson et al., 1997; Ehrenfeld, 2003). Symbiotic association with Frankia promoted successful invasion of Myrica faya Ait., in Hawaii (Vitousek et al., 1987). Non-native grass, Bromus diandrus Roth grown in lupine soil (Lupinus arboreus Sims) accumulated more shoot and root biomass when compared to $B$. diandrus grown in lupine soil. This proved that native lupines promote invasion of invasive grasses and forbs through nutrient enrichment brought about by symbiotic nitrogen fixation (Maron \& Connors, 1996). High diversity of nitrogen fixing bacteria (Arthrobacter, Mitsuaria, Burkholderia, Sinorhizobium, Pseudomonas, and Rhizobium) was observed in the rhizosphere of Ageratina adenophora invaded areas than in the uninvaded areas (Zhang et al., 2012).

A root nodulating legume, Cystisus scoparius (L.) Link seedlings were experimentally grown in old habitat field with or without Bradyrhizobium strains inoculum from other existing C. scoparius plant in the invasive region and resulted in low biomass and nodulation in absence of inoculum (Parker et al., 2006). A comparison of the genetic diversity of Bradyrhizobium associated with Acacia longifolia (Andr.) Willd. (invasive leguminous tree) in invaded regions showed that the diversity of Bradyrhizobium kept changing since the invasion and higher genetic diversity of $A$. longifolia associated rhizobia were observed in established areas than areas under invasion (Parker et al., 2002). An investigation on the diversity and identity of the rhizobial population nodulating an invasive legume tree $A$. mearnsii in natural Quercus suber L., forest revealed adaptation of Bradyrhizobium population to new soil environment following invasion (Boudiaf et al., 2014).

Based on the negative effects of invasive plants on the mycorrhizal association, Inderjit and van der Putten (2010) suggested that they may exert similar negative effects on the association between plant symbionts and nitrogen fixing bacteria. The invasion of Amaranthus viridis L., re- stricts the nodulation of Acacia sp. and reduces the growth of 30 strains of rhizobia originating from different regions in Africa (Sanon et al., 2011). The nitrogen fixing bacterial endophytes, Herbaspirillum seropedicae (Leifson) Ding and Yokota, Pseudomonas jessenii Verhille et al., Sphingobium amiense Ushiba et al., Caulobacter vibroides Henrici \& Johnson isolated from invasive grass Sorghum halepense (L.) Pers., account for changes in the biochemical cycles (nitrogen, phosphorous and iron) and thus enhance the growth and competitive ability of invasive plants (Rout \& Chrzanowski, 2009; Rout et al., 2013).

\section{Influence of soil enzymes and nutrients on plant invasion}

Exotic alien plant species affect the diversity of soil microbial communities. Soil microorganisms produce soil enzymes that may influence the litter decomposition, soil nutrients availability and ecosystem processes (Aon \& Colaneri, 2001; Marchante et al., 2008; Flory \& Clay, 2010). Soil pH plays an important role in bacterial and fungal growth and soil enzyme activity (Aon \& Colaneri, 2001). Generally, in most of the cases, soil enzymes are considered as the representative of nutrient cycles especially, carbon, nitrogen and phosphorus (Aon \& Colaneri, 2001). For example, protease is mostly found in active soil rich in humus and water contents and plays a vital role in mineralization of nitrogen (Utobo \& Tewari, 2015), $\beta$-glucosidases helps in degradation of plant residues, soil organic matters and has an important function in the carbon cycle. They also increase the soil microbial biomass and hence provide available nutrients for plants (Stott et al., 2010). Phosphatases and ureases are involved in phosphorous and nitrogen mineralization respectively (Sardans et al., 2008). Extracellular enzyme signifies the relationship between microbial activity, litter decomposition and nutrient accessibility (Aragón et al., 2014). Extracellular enzymes break down complex macromolecules into soluble sugars that are used as a source of energy and nutrients by enzyme producing organisms (Burns et al., 2013) They are also known to mineralize nitrogen and carbon (Allison et al., 2006). The resource allocation and growth pattern of native plant species differ from the exotic invasive plants (Liao et al., 2007). Native plants often accumulate greater concentration of specific nutrients that might influence the soil microbial structure and function (Batten et al., 2006). Contrarily, invasive plant species induce changes in the uptake of soil resources especially water and nutrients thus affecting the soil enzyme activity by altering the availability of soil nutrients (Allison \& Vitousek, 2004). The response of soil microbial community depends on the metabolites secreted by invasive plant species and result in altered meta- 
bolic activity of soil microbes (Marchante et al., 2008). In a greenhouse experiment, endocellulase, aminopeptidase, alkaline phosphatase, and phenol oxidase activities were increased in plant invaded soil when compared with native soil (Kourtev et al., 2003).

Soil enzyme activity depends on the characters of microbial communities and organic matter content in the soil (Allison \& Vitousek, 2004). A number of studies were carried out to check the impact of alien plant species invasion on soil enzyme activity (Li et al., 2006; Allison et al., 2006; Fan et al., 2010). Soil under plant invasion [B. thunbergii and Microstegium vimineum (Trin.) A. Camus] had increased level of chitobiase and aminopeptidase activities that are associated with nitrification while in soil from native plant species (Vaccinium sp.) had higher cellulolytic and phosphatase activities (Kourtev et al., 2002). Alkaline and acid phosphatase activities were higher in the areas of Solidago gigantea Ait., invasion (Chapuis-Lardy et al., 2006). Similarly, phosphatase and urease activities increased following the Falcataria moluccana (Miq.) Barne \& J.W. Grimes invasion (Allison et al., 2006). Chacon et al. (2009) observed that both, native and nonnative plant species had almost similar phosphatase activity although the concentration of phosphorous was higher in the roots of the invasive plant, Kalanchoe daigremontiana (Raym.Hamet \& H. Perrier) A. Berger. The soil enzymatic activity of acid and alkaline phosphatases as well as the microbial activities of fluorescein diacetate and dehydrogenase was reduced in pasture ecosystem after the introduction of the exotic Eucalyptus grandis W. Hill (Liao et al., 2007). The urease activity was higher in $K$. daigremontiana invaded soil than soils under native vegetation (Chacon et al., 2009). Most of the studies indicate that exotic invasive plant species alter nutrient cycling through their influence of soil microbes (Weidenhamer \& Callaway, 2010). Plant invasion increased nutrient pool sizes (carbon and nitrogen) and decomposition rates of belowground and aboveground in its invaded regions than native range (Liao et al., 2007). Lantana camara L., invasion in India resulted in increased soil nitrogen availability, higher ammonification and nitrification rates (Sharma \& Raghubanshi, 2009). Likewise, Alliaria petiolata invading soils in the North American temperate deciduous forest were characterized by the higher availability of nitrogen, phosphorous, calcium and magnesium and higher soil $\mathrm{pH}$. Invasion of C. maculosa decreased the availability of phosphorous in the soil, but the availability of phosphorous in the soil increased when this weed was eliminated using herbicides (Weidenhamer \& Callaway, 2010).

Higher litter inputs of Eucalyptus camaldulensis Dehnh. was reported in the riparian soil of invaded region than in the native region (Tererai et al., 2015). Increased concentrations of nitrogen, carbon and phosphorous were recorded in the top $15 \mathrm{~cm}$ soil after Amaranthus viridis
L., invasion (Sanon et al., 2009). Higher growth rates and maximum photosynthetic rates in five groups of invasive species in rainforests of Hawaii than four groups of native plant species were reported (Pattison et al., 1998). The invasive trees, Ailanthus altissima (Mill.) Swingle and $R$. pseudoacacia produced more litter than the native trees, thus indicating that invasive species can alter soil properties and litter dynamics (Medina-Villar et al., 2015). A. longifolia, a nitrogen fixing invasive tree accumulated litter inputs, thereby increasing the soil nitrogen content and hastened litter decomposition in invaded than in native ranges. Further A. longifolia invasion over a longer duration altered the soil properties by increasing the microbial biomass and basal respiration (Marchante et al., 2008). Populations of soil fungi and bacteria mostly correlate negatively with nitrogen mineralization rates leading to altered soil microbial communities which subsequently affect soil nitrogen cycle (Smithwick et al., 2012).

\section{Future perspectives and conclusion}

Studies on the role of soil rhizosphere microbiota in either promoting or inhibiting plant invasion are increasing. Most of the researchers have shown a microbial shift of the invasive plant species from its native region to its exotic region, but the stage-wise changes occurring during the process of plant invasion is not well known. While a number of studies have focused on soil pathogens and symbionts, the influence of saprophytes and decomposers on plant invasion is largely unexplored. Isolation of microbes from both invaded and uninvaded ecosystems of invasive plant species through modern techniques like, pyrosequencing could provide intense knowledge on identification, abundance, and composition of the soil biota. Additionally, the beneficial and detrimental aspects of isolated microbes in relation to native plant species could also be analyzed. Specific or a particular microbe that colonizes well with the invasive plant in its introduced range could be determined to get a clear idea about plant-soil-microbial interactions. Investigations on soil enzymes and nutrients in both introduced and native habitats for individual native plant species could be useful. The results obtained from the experiments carried out in laboratories or in greenhouse conditions differed from those observed under natural field conditions. Therefore, intensive field studies could provide further knowledge on pre and post changes occurred in both native and exotic ranges.

\section{References}

Agrawal A.A., Kotanen P.M., Mitchell C.E., Power A. G., Godsoe W. \& Klironomos J., 2005, Enemy release? 
An experiment with congeneric plant pairs and diverse above and belowground enemies, Ecology 86: 29792989.

Allen E.B. \& Allen M.F., 1984, Competition between plants of different successional stages: mycorrhizae as regulators, Canadian Journal of Botany 62: 2625-2629.

Allen M.F., 1991, The ecology of mycorrhizae, Cambridge University Press, Cambridge, UK.

Allison S.D., Nielsen C. \& Hughes R.F., 2006, Elevated enzyme activities under the invasive nitrogen fixing tree Falcataria moluccana, Soil Biology and Biochemistry $38: 1537-1544$.

Allison S.D. \& Vitousek P.M., 2004, Rapid nutrient cycling in leaf litter from invasive species in Hawai'i, Oecologia 141: $612-619$.

Andonian K., Hierro J.L., Khetsuriani L., Becerra P., Janoyan G., Villarreal D., Cavieres L., Fox L.R. \& Callaway R.M., 2011, Range expanding populations of a globally introduced weed experience negative plant-soil feedbacks, PLoS ONE 6: e20117.

Aon M.A.\& Colaneri A.C., 2001, Temporal and spatial evolution of enzymatic activities and physico-chemical properties in an agricultural soil, Applied Soil Ecology 18: 255-270.

Aragón R., Sardans J. \& Peñuelas J., 2014, Soil enzymes associated with carbon and nitrogen cycles in invaded and native secondary forests of northwestern Argentina, Plant and Soil 384: 169-183.

Barto E.K., Powell J.R. \& Cipollini D., 2010, How novel are the chemical weapons of garlic mustard in North American forest understories?, Biological Invasions 12: 3465-3471.

Batten K.M., Scow K.M., Davies K.F. \& Harrison S.P., 2006, Two invasive plants alter soil microbial community composition in serpentine grasslands, Biological Invasions 8: 217-230.

Batten K.M., Scow K.M., Espeland E.K, 2008, Soil microbial community associated with an invasive grass differentially impacts native plant performance, Microbial Ecology 55: 220-228.

Beckstead J. \& Parker I.M., 2003, Invasiveness of Ammophila arenaria: Release from soil-borne pathogens?, Ecology 84: 2824-2831.

Bever J.D., 2003, Soil community feedback and the coexistence of competitors: conceptual frameworks and empirical tests, New Phytologist 157: 465-473.

Bever J.D., Westover K. M. \& Antonovics J., 1997, Incorporating the soil community into plant population dynamics: the utility of the feedback approach, Journal of Ecology 85: 561-573.

Blossey B. \& Notzold R., 1995, Evolution of increased competitive ability in invasive nonindigenous plants: a hypothesis, Journal of Ecology 83: 887-889.
Blumenthal D.M., 2009, Carbon addition interacts with water availability to reduce invasive forb establishment in a semi-arid grassland, Biological Invasions 11: 1281-1290.

Boudiaf I., Le Roux C., Baudoin E., Galiana A., Beddiar A., Prin Y. \& Duponnois R., 2014, Soil Bradyrhizobium population response to invasion of a natural Quercus suber forest by the introduced nitrogen-fixing tree $\mathrm{Aca}$ cia mearnsii in El Kala National Park, Algeria, Soil Biology and Biochemistry 70: 162-165.

Broz A.K., Manter D.K. \& Vivanco J.M., 2007, Soil fungal abundance and diversity: another victim of the invasive plant Centaurea maculosa, International Society for Microbial Ecology 8: 763-765.

Bunn R.A., Ramsey P.W. \& Lekberg Y., 2015, Do native and invasive plants differ in their interactions with arbuscular mycorrhizal fungi? A meta-analysis, Journal of Ecology 103: 1547-1556.

Burns R.G., DeForest J., Marxsen J., Sinsabaugh R., Stromberger M.E., Wallenstein M., Weintraub M.N. \& Zoppini A., 2013, Soil enzymes in a changing environment: Current knowledge and future directions, Soil Biology and Biochemistry 58: 216-234.

Callaway R.M., Bedmar E.J., Reinhart K.O., Silvan C.G. \& Klironomos J., 2011, Effects of soil biota from different ranges on Robinia invasion: acquiring mutualists and escaping pathogens, Ecology 92: 1027-1035.

Callaway R.M., Cipollini D., Barto K., Thelen G.C., Hallet S.G., Prati D., Stinson K. \& Klironomos J., 2008, Novel weapons: invasive plant suppresses fungal mutualists in America but not in its native Europe, Ecology 89: 1043-1055.

Callaway R.M. \& Ridenour W.M., 2004, Novel weapons: invasive success and the evolution of increased competitive ability, Frontiers in Ecology and the Environment 2: 436-443.

Callaway R.M., Thelen G.C., Rodriguez A. \& Holber W. E., 2004, Soil biota and exotic plants invasion, Nature 427: 731-733.

Castelli J.P. \& Casper B.B., 2003, Intraspecific AM fungal variation contributes to plant-fungal feedback in serpentine grassland, Ecology 84: 323-336.

Chacón N., Herrera I., Flores S., González J.A. \& Nassar J.M., 2009, Chemical, physical, and biochemical soil properties and plant roots as affected by native and exotic plants in Neotropical arid zones, Biology and Fertility of Soils 45: 321-328.

Chapuis-Lardy L., Vanderhoeven S., Dassonville N., Koutika L.S. \& Meerts P., 2006, Effect of the exotic invasive plant Solidago gigantea on soil phosphorus status, Biology and Fertility of Soils 42: 481-489.

Chen W.M., de Faria S.M., Straliotto R., Pitard R.M., Simões-Araùjo J.L., Chou J.H., Chou Y.J., Barrios E., Prescott A.R., Elliott G.N., Sprent J.I., Young P.W. 
\& James E.K., 2005a, Proof that Burkholderia forms effective symbioses with legumes: a study of novel Mimosa-nodulating strains from South America, Applied and Environmental Microbiology 71: 7461-7471.

Chen W.M., James E.K., Chou J.H., Sheu S. Y., Yang S. Z. \& Sprent J. I., 2005b, Beta-rhizobia from Mimosa pigra a newly discovered invasive plant in Taiwan, New Phytologist 168: 661-675.

Chen W.M., Moulin L., Bontemps C., Vandamme P., Béna G. \& Boivin-Masson C., 2003, Legume symbiotic nitrogen fixation by $\beta$-Proteobacteria is widespread in nature, Journal of Bacteriology 185: 7266-7272.

Chen W.M., Laevens S., Lee T.M., Coenye T., de Vos P., Mergeay M. \& Vandamme P., 2001. Ralstonia taiwanensis sp. nov., isolated from root nodules of Mimosa species and sputum of a cystic fibrosis patient. International Journal of Systematic and Evolutionary Microbiology 51: 1729-1735.

Clawson M.L., Benson D.R., Resch S.C., Stephens D.W. \& Silvester W.B., 1997, Typical Frankia infect actinorhizal plants exotic to New Zealand, New Zealand Journal of Botany 35: 361-367.

Coats V.C. \& Rumpho M.E., 2014, The rhizosphere microbiota of plant invaders: an overview of recent advances in the microbiomics of invasive plants, Frontiers in Microbiology 5: 368 .

Colautti R.I. \& MacIsaac H.J., 2004, A neutral terminology to define invasive species, Diversity and Distributions 10: $135-141$.

Cui Q.G. \& He W.M., 2009, Soil biota, but not soil nutrients, facilitate the invasion of Bidens pilosa relative to a native species Saussurea deltoidea, Weed Research 49: 201-206.

Dai Z.C., Fu W., Qi S.S., Zhai D.L., Chen S.C., Wan L.Y., Huang P. \& Du D.L., 2016, Different responses of an invasive clonal plant Wedelia trilobata and its native congener to gibberellin: implications for biological invasion, Journal of Chemical Ecology 42: 85-94.

Davis M.A., Grime J.P. \& Thompson K., 2000, Fluctuating resources in plant communities: a general theory of invisibility, Journal of Ecology 88: 528-534.

Diez J., 2005, Invasion biology of Australian ectomycorrhizal fungi introduced with eucalypt plantations into the Iberian Peninsula, Biological Invasions 7: 3-15.

Dugar G., Gopinath B., Arun B. \& Sharma S., 2013, Plant growth promoting abilities of phosphate solubilizers from the rhizosphere of Parthenium hysterophorus, African Journal of Microbiology Research 7: 147-151.

Ehrenfeld J.G., 2003 Effects of exotic plant invasions on soil nutrient cycling processes, Ecosystems 6: $503-523$.

Eppinga M.B., Rietkerk M., Dekker S.C., De Ruiter P.C. \& van der Putten W.H., 2006, Accumulation of local pathogens: a new hypothesis to explain exotic plant invasions, Oikos 114: 168-176.

Fan L., Chen Y., Yuan J.G. \& Yang Z.Y., 2010, The effect of Lantana camara Linn. invasion on soil chemical and microbiological properties and plant biomass accumulation in Southern China, Geoderma 154: 370-378.

Flory S.L. \& Clay K., 2010, Non-native grass invasion alters native plant composition in experimental communities, Biological Invasions 12: 1285-1294.

Fumanal B., Plenchette C., Chauvel B. \& Bretagnolle F., 2006, Which role can arbuscular mycorrhizal fungi play in the facilitation of Ambrosia artemisiifolia L. invasion in France?, Mycorrhiza 17: 25-35.

Garbelotto M., Hüberli D. \& Shaw D., 2006, First report on an infestation of Phytophthora cinnamomi in natural oak woodlands of California and its differential impact on two native oak species, Plant Disease 90: 685.

Goodwin J., 1992, The role of mycorrhizal fungi in competitive interactions among native bunchgrasses and alien weeds: a review and synthesis, Northwest Science 66: 251-260.

Hawkes C.V., Wren I.F., Herman D.J. \& Firestone M.K., 2005, Plant invasion alters nitrogen cycling by modifying the soil nitrifying community, Ecology Letters 8: 976-985.

Herr C., Chapuis-Lardy L., Dassonville N., Vanderhoeven S. \& Meerts P., 2007, Seasonal effect of exotic invasive plant Solidago gigantea on soil $\mathrm{pH}$ and $\mathrm{P}$ fractions, Journal of Plant Nutrition and Soil Science 170: 729-738.

Inderjit. \& Cahill J.F., 2015, Linkages of plant-soil feedbacks and underlying invasion mechanisms, AoB PLANTS 7: plv022.

Inderjit. \& van der Putten W.H., 2010, Impacts of soil microbial communities on exotic plant invasions, Trends in Ecology and Evolution 25: 512-519.

Jeyalakshmi C., Doraisamy S. \& Valluvaparidasan V., 2011, Occurrence of soil microbes under Parthenium weed in Tamil Nadu, Indian Journal of Weed Science 43: 222-223.

Johnson N.C., Graham J.H. \& Smith F.A., 1997, Functioning of mycorrhizal associations along the mutualizmparasitism continuum, New Phytologist 135: 575-585.

Kardol P., Bezemer T.M. \& van der Putten W.H., 2006, Temporal variation in plant-soil feedback controls succession, Ecology Letters 9: 1080-1088.

Kardol P., Cornips N.J., van Kempen M.M.L., Bakx-Schotman J.M.T. \& van der Putten W.H., 2007, Microbemediated plant-soil feedback causes historical contingency effects in plant community assembly, Ecological Monographs 77: 147-162.

Keane R.M. \& Crawley M.J., 2002, Exotic plant invasions and the enemy release hypothesis, Trends in Ecology and Evolution 17: 164-170. 
Klironomos J.N., 2002, Feedback with soil biota contributes to plant rarity and invasiveness in communities, Nature 417: 67-70.

Kolar C.S. \& Lodge D.M., 2001, Progress in invasion biology: predicting invaders, Trends in Ecology and Evolution 16: 199-205.

Kourtev P.S., Ehrenfeld J.G. \& Häggblom M., 2002, Exotic plant species alter the microbial community structure and function in the soil, Ecology 83: 3152-3166.

Kourtev P.S., Ehrenfeld J.G. \& Häggblom M., 2003, Experimental analysis of the effect of exotic and native plant species on the structure and function of soil microbial communities, Soil Biology and Biochemistry 35: 895-905.

Kuebbing S.E., Classen A.T. \& Simberloff D., 2014, Two co-occurring invasive woody shrubs alter soil properties and promote subdominant invasive species, Journal of Applied Ecology 51: 124-133.

Kuebbing S.E. \& Nuñez M.A., 2015, Negative neutral and positive interactions among nonnative plants: patterns, processes and management implications, Global Change Biology 21: 926-934.

Kulmatiski A., Beard K.H., Stevens J.R. \& Cobbold S.M., 2008, Plant-soil feedbacks: a meta-analytical review, Ecology Letters 11: 980-992.

Kulmatiski A. \& Kardol P., 2008, Getting plant-soil feedbacks out of the greenhouse: experimental and conceptual approaches, [in:] Progress in Botany, U. Lüttge, W. Beyschlag \& J. Murata (eds), Springer-Verlag, Berlin Heidelberg: 449-472.

Larimer A.L., Bever J.D. \& Clay K., 2010, The interactive effects of plant microbial symbionts: a review and meta-analysis, Symbiosis 51: 139-148.

Le Roux J.J., Mavengere N.R. \& Ellis A.G., 2016, The structure of legume-rhizobium interaction networks and their response to tree invasions, AoB PLANTS 8: plw038

Levine J.M., Adler P.B. \& Yelenik S.G., 2004, A metaanalysis of biotic resistance to exotic plant invasions, Ecology Letters 7: 975-989.

Levine J.M., Vila M., D’Antonio C.M., Dukes J.S., Grigulis K. \& Lavorel S., 2003, Mechanisms underlying the impacts of exotic plant invasions, Proceedings of the Royal Society of London B, 270: 775-781.

Li D., Huang Y., Song S., Xue C., Wu Y. \& Deng X., 2015, Kibdelosporangium lantanae sp. nov., isolated from the rhizosphere soil of an ornamental plant, Lantana camara L., International Journal of Systematic and Evolutionary Microbiology 65: 2581-2585.

Li H., Shao J.J., Qiu S.Y. \& Li B., 2013 Native Phragmites dieback reduced its dominance in the salt marshes invaded by exotic Spartina in the Yangtze River estuary, China, Ecological Engineering 57: 236-241.
Li W.H., Zhang C.B., Jiang H.B., Xin G.R. \& Yang Z.Y., 2006, Changes in soil microbial community associated with invasion of the exotic weed, Mikania micrantha H.B.K, Plant and Soil 281: 309-324.

Liao C., Peng R., Luo Y., Zhou X., Wu X., Fang C., Chen J. \& Li B., 2007, Altered ecosystem carbon and nitrogen cycles by plant invasion: a meta-analysis, New Phytologist 177: 706-714.

Liu H. \& Stiling P., 2006, Testing the enemy release hypothesis: a review and meta-analysis, Biological Invasions 8: 1535-1545.

Lorenzo P., Rodríguez-Echeverrí S., LuísGonzález L. \& Freitas H., 2010, Effect of invasive Acacia dealbata Link on soil microorganisms as determined by PCRDGGE, Applied Soil Ecology 44: 245-251.

Mack R.N., 2001, Motivations and consequences of the human dispersal of plants, [in:] The Great Reshuffling: Human Dimensions of Invasive Alien Species, J.A. McNeely (eds), International Union for Conservation of Nature, Gland, Switzerland: 23-34.

Majewska M.L., Rola K. \& Zubek S., 2017, The growth and phosphorus acquisition of invasive plants Rudbeckia laciniata and Solidago gigantea are enhanced by arbuscular mycorrhizal fungi, Mycorrhiza 27: 83-94.

Mangan S.A., Schnitzer S.A., Herre E.A., Mack K.M.L., Valencia M.C., Sanchez E.I. \& Bever J.D., 2010, Negative plant-soil feedback predicts tree-species relative abundance in a tropical forest, Nature 466: 752-755.

Mangla S., Inderjit. \& Callaway R.M., 2008, Exotic invasive plant accumulates native soil pathogens which inhibit native plants, Journal of Ecology 96: 58-67.

Marchante E., Kjøller A., Struwe S. \& Freitas H., 2008, Invasive Acacia longifolia induce changes in the microbial catabolic diversity of sand dunes, Soil Biology and Biochemistry 40: 2563-2568.

Marler M.J., Zabinski C.A. \& Callaway R.M., 1999, Mycorrhizae indirectly enhance competitive effects of an invasive forb on a native bunchgrass, Ecology 80: 1180-1186.

Maron J.L. \& Connors P.G., 1996, A native nitrogen-fixing shrub facilitates weed invasion, Oecologia 105: 302312 .

Maron J., Klironomos J., Waller L.P. \& Callaway R.M., 2014, Invasive plants escape from suppressive soil biota at regional scales, Journal of Ecology 102: 19-27.

Medina-Villar S., Castro-Díez P., Alonso A., Cabra-Rivas I., Parker I.M. \& Pérez-Corona E., 2015, Do the invasive trees, Ailanthus altissima and Robinia pseudacacia, alter litterfall dynamics and soil properties of riparian ecosystems in Central Spain?, Plant and Soil 396: 311-324.

Meinhardt K.A. \& Gehring C.A., 2012, Disrupting mycorrhizal mutualisms: a potential mechanism by which 
exotic tamarisk outcompetes native cottonwoods, Ecological Applications 22: 532-549.

Mitchell C.E., Agrawal A.A., Bever J.D., Gilbert G.S., Hufbauer R.A., Klironomos J.N., Maron J.L., Morris W.F., Parker I.M., Power A.G., Seabloom E.W., Torchin M.E. \& Vázquez D.P., 2006, Biotic interactions and plant invasions, Ecology Letters 9: 726-740.

Mitchell C.E. \& Power A.G., 2003, Release of invasive plants from fungal and viral pathogens, Nature 421: 625-27.

Mooney H.A. \& Cleland E.E., 2001, The evolutionary impact of invasive species, Proceedings of the National Society of Sciences of the United States of America 98: 5446-5451.

Moore P.D., 2004, Plant ecology: favoured aliens for the future, Nature 427: 594-594.

Mummey D.L. \& Rillig M.C., 2006, The invasive plant species Centaurea maculosa alters arbuscular mycorrhizal fungal communities in the field, Plant and Soil 288: 81-90.

Neuhauser C. \& Fargione G.E., 2004, A mutualism-parasitism continuum model and its application to plantmycorrhizae interactions, Ecological Modelling 177: 335-352.

Newcombe G., Shipunov A., Eigenbrode S., Raghavendra A.K.H., Ding H., Anderson C.L., Menjivar R., Crawford M. \& Schwarzländer M., 2009, Endophytes influence protection and growth of an invasive plant, Communicative and Integrative Biology 2: 29-31.

Niu H.B., Liu W.X., Wan F.H. \& Liu B., 2007a, An invasive aster (Ageratina adenophora) invades and dominates forest understories in China: altered soil microbial communities facilitate the invader and inhibit natives, Plant and Soil 294: 73-85.

Niu H.B., Liu W.X., Wan F.H. \& Liu B., 2007b, Screening, identification and antagonism assessment of dominant bacteria in Ageratina adenophora Sprengel rhizosphere soil, Journal of Applied Ecology 18: 2795-2800.

Novoa A., Rodríguez R., Richardson D. \& González L., 2014, Soil quality: a key factor in understanding plant invasion? The case of Carpobrotus edulis (L.) N.E. Br., Biological Invasions 16: 429-443.

Ogle S., Reiners W. \& Gerow K., 2003, Impacts of exotic annual Brome grasses (Bromus spp.) on ecosystem properties of Northern mixed grass prairie, The American Midland Naturalist 149: 46-58.

Packer A. \& Clay K., 2000, Soil pathogens and spatial patterns of seedling mortality in a temperate tree, Nature 404: 278-281.

Panetta F.D. \& Scanlan J.C., 1995, Human involvement in the spread of noxious weeds: what plants should be declared and when should control be enforced?, Plant Protection Quarterly 10: 69-74.
Parker M. A, Lafay B., Burdon J.J. \& van Berkum P., 2002, Conflicting phylogeographic patterns in rRNA and nifD indicate regionally restricted gene transfer in Bradyrhizobium, Microbiology 148: 2557-2565.

Parker M.A., Malek W. \& Parker I.M., 2006, Growth of an invasive legume is symbiont limited in newly occupied habitats, Diversity and Distribution 12: 563-571.

Pattison R.R., Goldstein G. \& Ares A., 1998, Growth, biomass allocation and photosynthesis of invasive and native Hawaiian rainforest species, Oecologia 117: 449459.

Pringle A., Bever J.D, Gardes M., Parrent J.L., Rillig M.C. \& Klironomos J.N., 2009, Mycorrhizal symbioses and plant invasions, Annual Review of Ecology, Evolution and Systematics 40: 699-715.

Reinhart K.O. \& Callaway R.M., 2004, Soil biota facilitate exotic Acer invasions in Europe and North America, Ecological Applications 14: 1737-1745.

Reinhart K.O. \& Callaway R.M., 2006, Soil biota and invasive plants, New Phytologist 170: 445-457.

Reinhart K.O., Packer A., van der Putten W.H. \& Clay K., 2003, Plant-soil biota interactions and spatial distribution of black cherry in its native and invasive ranges, Ecology Letters 6: 1046-1050.

Reinhart K.O., Tytgat T., van der Putten W.H. \& Clay K., 2010, Virulence of soil-borne pathogens and invasion by Prunus serotina, New Phytologist 186: $484-495$.

Richardson D.M., Allsopp N., D’Antonio C.M., Milton S.J. \& Rejmánek M., 2000, Plant invasions - the role of mutualisms, Biological Reviews 75: 65-93.

Richardson D.M., Williams P.A. \& Hobbs R.J., 1994, Pine invasions in the southern hemisphere- determinants of spread and invadability, Journal of Biogeography 21: $511-527$.

Roberts K.J \& Anderson R.C., 2001, Effect of garlic mustard [Alliaria petiolata (Beib. Cavara \& Grande)] extracts on plants and arbuscular mycorrhizal (AM) fungi, The American Midland Naturalist 146: 146-152.

Rout M.E., \& Callaway R.M., 2012, Interactions between exotic invasive plants and soil microbes in the rhizosphere suggest that 'everything is not everywhere, Annals of Botany 110: 213-222.

Rout M.E. \& Chrzanowski T.H., 2009, The invasive Sorghum halepense harbors endophytic $\mathrm{N}_{2}$-fixing bacteria and alters soil biogeochemistry, Plant and Soil 315: 163-172.

Rout M.E., \& Chrzanowski T.H., Westlie T.K., DeLuca T.H., Callaway R.M. \& Holben W.E., 2013, Bacterial endophytes enhance competition by invasive plants, American Journal of Botany 100: 1726-1737.

Ruckli R., Rusterholz H.P. \& Baur B., 2014, Invasion of an annual exotic plant into deciduous forests suppresses arbuscular mycorrhiza symbiosis and reduces perfor- 
mance of sycamore maple saplings, Forest Ecology and Management 318: 285-293.

Sanon A., Beguiristain T., Cébron A., Berthelin J., Ndoye I., Leyval C., Sylla S. \& Duponnois R., 2009, Changes in soil diversity and global activities following invasions of the exotic invasive plant, Amaranthus viridis L., decrease the growth of native sahelian Acacia species, FEMS Microbiology Ecology 70: 118-131.

Sanon A., Beguiristain T., Cébron A., Berthelin J. \& Sylla S.N. \& Duponnois R., 2011, Differences in nutrient availability and mycorrhizal infectivity in soils invaded by an exotic plant negatively influence the development of indigenous Acacia species, Journal of Environmental Management 95: 275-279.

Sardans J., Peñuelas J. \& Estiarte M., 2008, Changes in soil enzymes related to $\mathrm{C}$ and $\mathrm{N}$ cycle and in soil $\mathrm{C}$ and $\mathrm{N}$ content under prolonged warming and drought in a Mediterranean shrubland, Applied Soil Ecology 39: 223-235.

Scharfy D., Güsewell S., Gessner M.O. \& Venterink H.O., 2010, Invasion of Solidago gigantea in contrasting experimental plant communities: effects on soil microbes, nutrients and plant-soil feedbacks, Journal of Ecology 98: 1379-1388.

Seifert E.K., Bever J.D. \& Maron J.L., 2009, Evidence for the evolution of reduced mycorrhizal dependence during plant invasion, Ecology 90: 1055-1062.

Shah M.A. \& Reshi Z., 2007 Invasion by alien Anthemis cotula L. in a biodiversity hotspot: release from native foes or relief from alien friends, Current Science 92: 21-22.

Shah M.A., Reshi Z. \& Rashid I., 2008, Mycorrhizal source and neighbour identity differently influence Anthemis cotula L. invasion in the Kashmir Himalaya, India, Applied Soil Ecology 40: 330-337.

Shannon S.M., Bauer J.T., Anderson W.E. \& Reynolds H.L., 2014, Plant-soil feedbacks between invasive shrubs and native forest understory species lead to shifts in the abundance of mycorrhizal fungi, Plant and Soil 382: 317-328.

Sharma G.P. \& Raghubanshi A.S., 2009, Lantana invasion alters soil nitrogen pools and processes in the tropical dry deciduous forest of India, Applied Soil Ecology 42: $134-140$

Shipunov A., Newcombe G., Raghavendra A.K. \& Anderson C. L., 2008, Hidden diversity of endophytic fungi in an invasive plant, American Journal of Botany 95: 1096-1108.

Si C., Liu X., Wang C., Wang L., Dai Z., Qi S. \& Du D., 2013, Different degrees of plant invasion significantly affect the richness of the soil fungal community, PLoS ONE 8: e85490.

Smith S.E. \& Read D.J., 2008, Mycorrhizal Symbiosis, 3 edn., Academic Press, London, UK.
Smithwick E.A.H., Naithani K.J., Balser T.C, Romme W.H. \& Turner M.G., 2012, Post-fire spatial patterns of soil nitrogen mineralization and microbial abundance, PLoS ONE 7 (11): e50597.

Stinson K.A., Campbell S.A., Powell J.R., Wolfe B.E., Callaway R.M., Thelen G.C., Hallett S.G., Prati D. \& Klironomos J.N., 2006, Invasive plant suppresses the growth of native tree seedlings by disrupting belowground mutualisms, PLoS Biology 12: e1001817.

Stott D.E., Andrews S.S., Liebig M.A., Wienhold B.J. $\&$ Karlen D.L., 2010, Evaluation of $\beta$-glucosidase activity as a soil quality indicator for the soil management assessment framework, Soil Biology and Biochemistry 74: $107-119$.

Suding K.N., Harpole W.S., Fukami T., Kulmatiski A., MacDougall A.S., Stein C. \& van der Putten W.H., 2013, Consequences of plant-soil feedbacks in invasion, Journal of Ecology 101: 298-308.

Sun Z.K. \& He W.M., 2010, Evidence for enhanced mutualism hypothesis: Solidago canadensis plants from regular soils perform better, PLoS ONE 5: e15418.

Te Beest M., Stevens N., Olff H. \& van der Putten W.H., 2009, Plant-soil feedback induces shifts in biomass allocation in the invasive plant Chromolaena odorata, Journal of Ecology 97: 1281-1290.

Tererai F., Gaertner M., Jacobs S.M. \& Richardson D.M., 2015, Eucalyptus camaldulensis invasion in riparian zones reveals few significant effects on soil physicochemical properties, River Research and Applications 31: 590-601.

Utobo E.B. \& Tewari L., 2015, Soil enzymes as bioindicators of soil ecosystem status, Applied Ecology and Environmental Research 13: 147-169.

van der Putten W.H., 2001, Interactions of plants, soil pathogens and their antagonists in natural ecosystems, [in:] Biotic interactions in plant-pathogen associations, M.J. Jeger, N.J. Spence (eds), CAB International, New York, NY, USA: 285-305.

van der Putten W.H., Bardgett R.D., Bever J.D., Bezemer T.M., Casper B.B., Fukami T., Kardol P., Klironomos J.N., Kulmatiski A., Schweitzer J.A., Suding K.N., Van de Voorde T.F.J. \& Wardle D.A., 2013, Plant-soil feedbacks: the past, the present and future challenges, Journal of Ecology 101: 265 -276.

van der Putten W.H., Kowalchuk G.A., Brinkman E.P., Doodeman G.T.A., van der Kaaij R.M., Kamp A.F., Menting F.B. \& Veenendaal E.M., 2007, Soil feedback of exotic savanna grass relates to the absence of pathogens and selective mycorrhizal fungi, Ecology 88: 978-988. van der Putten W.H., van Dijk C. \& Peters B., 1993, Plantspecific soilborne diseases contribute to succession in foredune vegetation, Nature 362: 53-56.

van der Putten W.H., Yeates G.W., Duyts H., Reis C.S. \& Karssen G., 2005, Invasive plants and their escape 
from root herbivory: a worldwide comparison of the root-feeding nematode communities of the dune grass Ammophila arenaria in natural and introduced ranges, Biological Invasions 7: 733-746.

van Kleunen M., Dawson W., Essl F., Pergl J., Winter M., Weber E., Kreft H., Weigelt P., Kartesz J., Nishino M., Antonova L.A., Barcelona J.F., Cabezas F.J., Cárdenas D., Cárdenas-Toro J., Castano N., Chacón E., Chatelain C., Ebel A.L., Figueiredo E., Fuentes N., Groom Q.J., Henderson L., Inderjit., Kupriyanow A., Patzelt A., Pelser P. B., Baptiste M.P., Poopath M., Schulze M., Seevbens H., Shu W.S., Thomas J., Velayos M., Wieringa J.J. \& Pyšek P., 2015, Global exchange and accumulation of non-native plants, Nature 525: 100-103.

Vellinga E.C., Wolfe B.E. \& Pringle A., 2009, Global patterns of ectomycorrhizal introductions, New Phytologist 181: 960-973.

Vilà M., Corbin J.D., Dukes J.S., Pino J. \& Smith S.D., 2007, Linking plant invasions to global environmental change, [in:] Terrestrial ecosystems in a changing world - The IGBP Series, J.G. Canadell, D.E. Pataki, L.F. Pitelka (eds), Springer New York, NY, USA: 93102.

Vilà M., Maron J.L. \& Marco L., 2005, Evidence for the enemy release hypothesis in Hypericum perforatum, Oecologia 142: 474-479.

Vilà M. \& Weiner J., 2004, Are invasive plant species better competitors than native plant species? Evidence from pair-wise experiments, Oikos 105: 229-238.

Vitousek P.M., Walker L.R., Whiteaker L.D., MuellerDombois D. \& Matson P.A., 1987, Biological invasion by Myrica faya alters ecosystem development in Hawaii, Science 238: 802-804.

Vogelsang K.M., Bever J.D., Griswold M. \& Schultz P.A., 2004, The Use of Mycorrhizal Fungi in Erosion Control Applications, California Department of Transportation, Sacramento, CA.

Wang C.Y., Han G.M., Jia Y., Feng X.G., Guo P. \& Tian X.J., 2011, Response of litter decomposition and related soil enzyme activities to different forms of nitrogen fertilization in a subtropical forest, Ecological Research 26: 505-513.

Wei G., Chen W., Zhu W., Chen C., Young J.P. \& Bontemps C., 2009, Invasive Robinia pseudoacacia in China is nodulated by Mesorhizobium and Sinorhizobium species that share similar nodulation genes with native American symbionts, FEMS Microbiology Ecology 68: 320-328.

Weidenhamer J.D. \& Callaway R.M., 2010, Direct and indirect effects of invasive plants on soil chemistry and ecosystem function, Journal of Chemical Ecology 36: 59-69.

Werner C., Zumkier U., Beyschlag W. \& Máguas C., 2010, High competitiveness of a resource demanding invasive acacia under low resource supply, Plant Ecology 206: 83-96.

Wolfe B.E. \& Klironomos J.N., 2005, Breaking new ground: soil communities and exotic plant invasion, BioScience 55: 477-487.

Wolfe B.E., Rodgers V.L., Stinson K.A. \& Pringle A., 2008, The invasive plant Alliaria petiolata (garlic mustard) inhibits ectomycorrhizal fungi in its introduced range, Journal of Ecology 96: 777-783.

Xiao H.F., Feng Y.L., Schaefer D.A. \& Yang X.D., 2014, Soil fungi rather than bacteria were modified by invasive plants, and that benefited invasive plant growth, Plant and Soil 378: 253-264.

Yang Q., Carrillo J., Jin H., Shang L., Hovick S. M., Nijjer S., Gabler C.A, Li B. \& Siemann E., 2013, Plant-soil biota interactions of an invasive species in its native and introduced ranges: implications for invasion success, Soil Biology and Biochemistry 65: 78-85.

Yang R., Zhou G., Zan S., Guo F., Su N. \& Li J., 2014, Arbuscular mycorrhizal fungi facilitate the invasion of Solidago canadensis L. in southeastern China, Acta Oecologica 61: 71-77.

Yelenik S.G., Stock W.D. \& Richardson D.M., 2004, Ecosystem Level Impacts of Invasive Acacia saligna in the South African Fynbos, Restoration Ecology 12: 44-51.

Zabinski C.A., Quinn L. \& Callaway R.M., 2002, Phosphorus uptake, not carbon transfer, explains arbuscular mycorrhizal enhancement of Centaurea maculosa in the presence of native grassland species, Fuctional Ecology 16: 758-765.

Zhang F., Guo J., Chen F., Liu W. \& Wan F., 2012, Identification of volatile compounds released by leaves of the invasive plant Crofton weed (Ageratina adenophora, Compositae), and their inhibition of rice seedling growth, Weed Science 60: 205-211.

Zhang Q., Yang R., Tang J., Yang H., Hu S. \& Chen X., 2010, Positive feedback between mycorrhizal fungi and plants influences plant invasion success and resistance to invasion, PLoS ONE 5, e12380.

Zhou P.F., Chen W.M. \& Wei G.H., 2010, Mesorhizobium robiniae sp. nov., isolated from root nodules of Robinia pseudoacacia, International Journal of Systematic and Evolutionary Microbiology 60: 2552-2556.

Zou J., Rogers W.E. \& Siemann E., 2008, Increased competitive ability and herbivory tolerance of the invasive plant Sapium sebiferum, Biological Invasions 10: 291302.

Zubek S., Majewska M.L., Błaszkowski J., Stefanowicz A.M., Nobis M. \& Kapusta P., 2016, Invasive plants affect arbuscular mycorrhizal fungi abundance and species richness as well as the performance of native plants grown in invaded soils, Biology and Fertility of Soils 52: 879-893. 